\title{
Impacts of Terrestrial Ionizing Radiation on the Hematopoietic System
}

\author{
Saman Shahid ${ }^{*}$, Muhammad Nawaz Chaudhry', Nasir Mahmood ${ }^{2}$, Shaharyar Sheikh ${ }^{3}$ \\ ${ }^{1}$ College of Earth and Environmental Sciences, University of the Punjab, Lahore, Pakistan \\ ${ }^{2}$ Department of Allied Health Sciences \& Chemical Pathology \\ and Department of Human Genetics \& Molecular Biology, \\ University of Health Sciences (UHS), Lahore, Pakistan \\ ${ }^{3}$ Shaikh Zayed Hospital, Federal Postgraduate Medical Institute, Lahore, Pakistan
}

Received: 5 January 2015

Accepted: 31 January 2015

\begin{abstract}
In Pakistan the Siwalik region is exposed to ionizing radiation (IR) from uranium mineralization. The current research describes the impact of long-term low-dose terrestrial ionizing radiation exposure on the hematopoietic indices of the region's inhabitants. Mean values of the selected complete blood count (CBC) parameters were calculated to examine low or high trend. A t-test was conducted on the mean values of CBC parameters to analyze parameters showing a significant difference between radiation-exposed people and radiation unexposed people. Most disturbed CBC parameters found low were: mean corpuscular hemoglobin (MCH) 52\%, mean corpuscular hemoglobin concentration (MCHC) 44\%, and platelets (PLT) $28 \%$. The most affected CBC parameter which was found to be high was lymphocyte count (LYM) $28 \%$. Seven CBC parameters, including hemoglobin (HB), white blood cells (WBC), platelets (PLT), hematocrit (HCT), neutrophils (NEUT), MCH, and MCHC, showed a decrease trend in radiation-exposed residents and two CBC parameters, including red blood cells (RBC) and LYM, showed an increased trend. Significant differences were found in the parameters viz., $\mathrm{HB}, \mathrm{WBC}, \mathrm{MCH}, \mathrm{MCHC}, \mathrm{HCT}$, and LYM by the t-test between radiation exposed and unexposed individuals. The odds of developing a low $\mathrm{MCH}$ were four times higher and the odds of developing a low MCHC were 4.4 times higher for radiation-exposed individuals as compared to radiation unexposed. The persistent low-dose IR exposure resulted in anemia and immune modulation in radiation-exposed residents.
\end{abstract}

Keywords: ionizing radiations, radionuclides, uranium, hematology, immunity

\section{Introduction}

It is known that the hematopoietic system, through its associated functional cells, transports oxygen in the blood and provides immune regulations, ensures coagulation of blood, and sustains intact blood vessels [1-5]. This system includes bone marrow (a major blood-forming system) and mature cells that circulate in the blood vessels [1, 6-8].

*e-mail: saman.shahid@gmail.com
This study was aimed to assess hematological alterations in the inhabitants from naturally occurring terrestrial ionizing radiation emerging from natural radionuclides due to uranium minerals present in soil or rocks. The Siwalik belt in Pakistan was selected. The inhabitants were exposed to radiation during agricultural activities, for example, through radioactive-contaminated tube well water. Although, the radiation dose was low, long-term and sustained exposure were suspected of posing serious health risks for such inhabitants. 
Ionizing radiation such as X-rays or gamma rays are energetic and high-frequency electromagnetic waves. Their exposure from the natural environment has been long studied and associated with serious health risks, including cancer [9-12]. The bone marrow system is highly radiosensitive and therefore analysis of hematopoietic indices for radiation-exposed people is emphasized. Blood-forming cells in bone marrow are highly vulnerable to radiation damage [13]. In Nigeria, it has been estimated that about 160 people annually are at cancer risk due to terrestrial gamma radiation exposure [14].

It is also known that natural background radiation is the most important source of human exposure in which a significant component of the background radiation is generated from natural radionuclides present in the soil $[15,16]$. Terrestrial radioactivity depends on different geological and geographical conditions around the world [17, 18]. Terrestrial radiation is initiated by radioactive chemicals that were present when the earth was formed. They are found in igneous, metamorphic, and sedimentary rocks in different regions of the world. Such radionuclides move into the water supply, soil, in the air, and other environmental components. Currently, uranium mining, industrial processes, or phosphate fertilizer production has contributed to the redistribution of the radionuclides. The presence of natural radioactivity in soil and other building materials results in internal and external exposure to the inhabitants $[19,20]$.

The following radionuclides: ${ }^{238} \mathrm{U},{ }^{232} \mathrm{Th},{ }^{40} \mathrm{~K}$, and their decay products that may be present in rocks, soils, and minerals in the ground emit penetrating gamma rays [21, 22]. In Kerala (India) and some parts of France and Brazil, the dose can be up to 20 times the global average. In some countries (e.g., Finland) the average dose is several times higher, and in particular, residents of many countries have received effective doses of the order of hundreds of milisieverts per year $[19,20]$. Uranium is a natural radioactive and chemotoxic heavy metal found in traces in soils, rocks, and plants, as well as in water sources [23-26]. Uranium238 is the parent to a long series of radionuclides of several elements. In this series, there is an isotope of the radioactive gas radon, known as radon-222, which can reach the atmosphere [19].

The Siwalik belt is $1,500 \mathrm{~km}$ long and passes through Southern Azad Jammu and Kashmir, Potwar, Southern Khyber Pakhtoonkhaw and Baluchistan [27-32]. The fluvial package present in the Siwalik region was found deposited by the braided rivers containing volcanic ash intervals as a source of uranium mineral anomalies [31, 32]. Some of the major uranium mineral deposits are found in the Sulaiman Range, Baghal Chur, Nangar Nai, Taunsa, Mochi Mar, and Shavah-Shanawah [27, 32-34]. In the Siwalik environment uranium and its daughters are present with elevated radon levels $[32,35]$. The uranium anomalies are also associated with the S-type granites, which are the basic type of granite, including muscovite and biotite enriched in aluminum, and granite gneisses of Lesser Himalayan and Higher Himalaya regions [32, 35].
The areas with exceptionally high background radioactivity are found in Yangjiang (China), Kerala (India), Guarapari (Brazil), Ramsar (Iran), and in the mountains of Serbia, where uranium ore has been exploited for many years. The terrestrial gamma radiation dose was found twofold higher than the background area [36, 37]. There are also small but numerous uranium deposits and crystalline rocks present in Kabul Khel, near Bannu Basin and Kallar Kahar near the Salt Range [32, 38].

Uranium mining and processing has presented a tremendous threat to workmen and the population living in the surrounding areas because of the radiation exposure $[25,39]$. Acid mine drainage is also a major mining-related environmental health problem [24, 40-43]. Variation in the neonatal death rate in the selected areas of the western United States has been studied related to the geological environment of the uranium reserves [44].

Anthropogenic activities have also increased uranium in the environment in the form of depleted uranium. Scientists have studied the influence of the use of uraniumcontaining phosphate fertilizers in agriculture. The results indicate that uranium applied to soils for fertilization accumulates in the soils, and that a nearby water aquifer gets contaminated by a significant amount of uranium through leakage $[25,45,46]$. It is important to note that the production and use of uranium phosphate fertilizers induces adverse effects on humans through environmental bioaccumulation and food-chain contamination [47]. Intake of uranium-contaminated water presents risks to bones, kidney, and liver due to the accumulated effects [25, 48]. Radon222 gas, even at lower doses, can enter the body through pulmonary alveoli; as a result, it can irradiate different organs, especially in the people who live near elevated levels of natural background radiation $[49,50]$. DNA damage and chromosomal aberrations were found in the peripheral blood lymphocytes and leukocytes of those workers who were exposed to uranium compounds emerging from lowdose radiation [51-56]. Also, mortalities from kidney, bladder, and esophagus cancers were likely to increase, but chronic renal diseases were observed to be significantly higher [57-59].

It is known that ionizing radiation impacts human health; break chemical bonds of the molecules and damage DNA by the production of free radicals and cells in growth can undergo apoptosis [60-63]. The stem cells are radiosensitive and their damage by radiation can result in non-functionality of the cells. Long-term exposure to even low doses of radiation can affect the proliferating cells [4, 64]. Ionizing radiation affects the organism through water radiolysis. DNA damage happens as a result of its interaction with reactive oxygen species. Cell death or its mutation may be a result of DNA damage. But the cell damage depends on the type of radiation, dose rate, and fractional dose $[65,66]$. Exposure from the ionizing radiation is sensitive for bone marrow, the gastrointestinal tract, and skin because their tissues turn over rapidly. Moreover, tissues of the central nervous system (CNS), lung, heart, liver, kidney, and gonads can be affected, whose turnover is slow [61, 67]. The lens of the 
eye is also considered one of the most radiosensitive tissues in the human body and cataractogenesis can happen as a result [68]. Energy from radiation leads to the formation of excited and ionized molecules. Much such damage is also produced because of oxidative stress induced by free radicals $[69,70]$.

Hematopoietic syndrome is caused by the effects of radiation on the bone marrow, spleen, and lymph nodes. Loss of appetite (anorexia), lethargy, nausea, and vomiting may begin after exposure. After such symptoms are resolved, the blood-forming cells in bone marrow, the spleen, and lymph nodes start to waste and do not tend to be replaced. Hence, the insufficiency of white blood cells is followed by a shortfall of platelets and red blood cells. Further, the shortage of white blood cells can trigger infections and the shortage of platelets can cause uncontrolled bleeding from body tissues $[71,72]$.

\section{Materials and Methods}

\section{Blood Sampling and Background Information Collection}

Blood samples from non-smoker individuals (1-ml) were collected by selecting age-matched volunteers by informed consent from terrestrial radiation-exposed people $(n=25)$. The control group $(n=31)$ was radiation-exposed people with the same socioeconomic background of radiation-exposed people. Information regarding age, sex, marital status, duration of radiation exposure, dietary habits, and occupation was taken on a designated Proforma.

\section{Complete Blood Count (CBC) Test}

The collected blood was mixed well and used Abacus + and Medonic machines for CBC tests. Nine CBC parameters were considered and analyzed for all groups in this study: hemoglobin (HB) in g/l, white blood cells (WBC) in $10 \%$, platelet count (PLT) in 10\%, hematocrit (HCT) in \%, red blood cells (RBC) in 10 $12 / 1$, mean corpuscular hemoglobin $(\mathrm{MCH})$ in $\mathrm{g} / \mathrm{l}$, mean corpuscular hemoglobin concentration (MCHC) in \%, lymphocytes (LYM) in \%, and neutrophils (NEUT) in \%.

\section{The t-test (Independent Samples Test) and Odds Ratios}

All statistical calculations were performed using SPSS21 software. All of the nine $\mathrm{CBC}$ parameters' mean values and mean values of those $\mathrm{CBC}$ parameters which were either below the normal range or above the normal range were calculated for all individuals. A t-test (independent samples test) was conducted on the mean values of nine CBC parameters to analyze parameters showing significant difference between radiation-exposed people and radiationunexposed people. Another t-test (independent samples test) was conducted on $\mathrm{CBC}$ parameters that were either below or above the normal range between radiationexposed people and radiation-unexposed people.

Odds ratios were calculated to find out the association of measure between radiation exposure and having an altered (low or high) $\mathrm{CBC}$ parameter. Pearson chi-square test was used to evaluate significance of a respective parameter through a $\mathrm{p}$-value $(\mathrm{p}<\alpha=0.05)$.

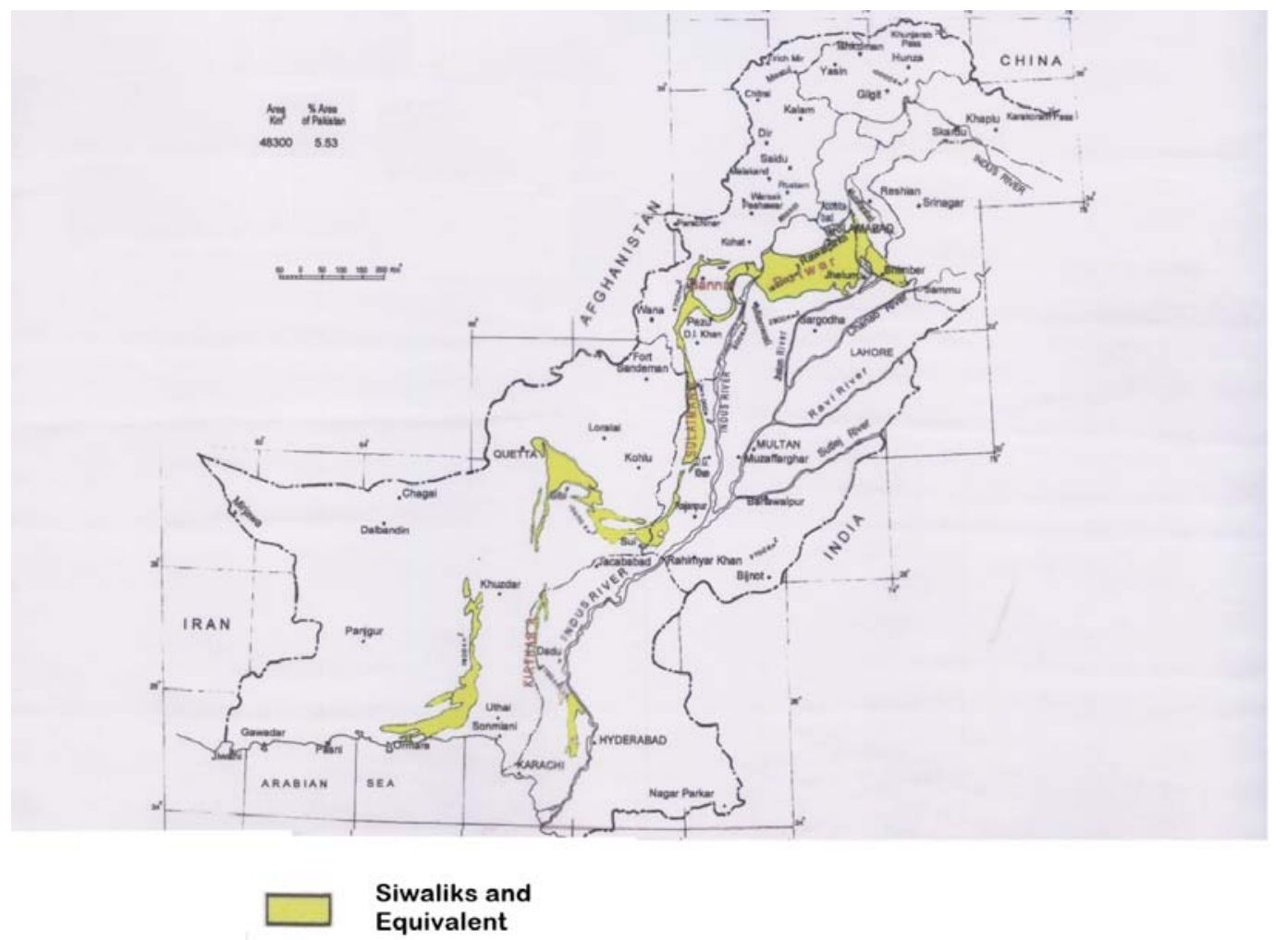

Fig. 1. Siwalik Belt [38]. 
Table 1. Background information of radiation-exposed residents (RERs).

\begin{tabular}{|c|c|c|c|}
\hline \multicolumn{2}{|c|}{ Parameters } & $\begin{array}{r}\text { Siwalik } \\
\text { residents }\end{array}$ & $\begin{array}{l}\text { Percentage } \\
\text { prevalence }\end{array}$ \\
\hline \multirow{3}{*}{ Age } & $18-25$ & 5 & 20 \\
\hline & $26-50$ & 15 & 60 \\
\hline & 51 and above & 5 & 20 \\
\hline \multirow{2}{*}{ Sex } & Male & 18 & 72 \\
\hline & Female & 7 & 28 \\
\hline \multirow{2}{*}{$\begin{array}{l}\text { Marital } \\
\text { Status }\end{array}$} & Married & 18 & 72 \\
\hline & Single & 7 & 28 \\
\hline \multirow{3}{*}{$\begin{array}{l}\text { Occupation/ } \\
\text { status }\end{array}$} & Farmers & 11 & 44 \\
\hline & Laborers & 10 & 40 \\
\hline & Field workers & 4 & 16 \\
\hline \multirow{2}{*}{$\begin{array}{l}\text { Drinking } \\
\text { water }\end{array}$} & Filtered & 2 & 8 \\
\hline & Unfiltered & 23 & 92 \\
\hline
\end{tabular}

\section{Results}

\section{Analysis of Background Information}

Twenty-five people were selected from different regions of Siwalik, Pakistan: Dera Ghazi Khan, Dera Ismail Khan, Bannu, and Isa-khel. Fig. 1 shows Siwalik belt mapped in yellow. All individuals were found having balanced food intake with non-alcoholic and non-smoking habits. Radiation doses for gamma activity from selected
Siwalik areas were measured from gamma and $\mathrm{X}$-ray scintillometer (SAPHYMO-SPP2 NF) [32]. The measurements were in the range of 200-450 counts per second (cps), which corresponds to: $0.4383-1.3149 \mathrm{mSv} / \mathrm{y}[32,38,73]$. Table 1 shows information for radiation-exposed residents; $72 \%$ were male, ages $26-50$ years. There were $44 \%$ farmers and $40 \%$ were laborers. These people were inhaling local natural radiation from naturally occurring radionuclides. These people were also exposed to natural radiation from their occupations, i.e., agricultural practices or by construction work. They may be further exposed to radon, from building materials, etc. It is reported that most of these people $(92 \%)$ were not having safe drinking water because terrestrial radionuclides such as uranium, thorium, radium226 , radium- 228 , and potassium- 40 eventually contaminate drinking water reserves [32]. All individuals from the control group were not found to be exposed to radiation either from the locality of their residence or from their profession.

\section{Hematological Profile}

Tables 2 and 3 show hematological profile. Most affected $\mathrm{CBC}$ parameter was low $\mathrm{MCH}(52 \%)$ in radiation residents as compared to the controls. The second most affected parameter was low MCHC (44\%), and the third most affected parameters were low PLT (28\%) and high LYM $(28 \%)$.

\section{Comparison of Mean Values of CBC Parameters with the Normal Range for Radiation-Exposed Residents (RERs)}

A significant number $(12 \%)$ of the radiation-exposed residents (RERs) had low HB (mean=10.33) as compared to the controls $(0 \%)$. Likewise, a significant number $(16 \%)$

Table 2. Mean values of complete blood count (CBC) for radiation-exposed residents (RERs) and the control group.

\begin{tabular}{|l|c|c|c|c|c|c|c|}
\hline \multirow{2}{*}{ Parameters } & \multicolumn{3}{|c|}{$\begin{array}{c}\text { Terrestrial radiation-exposed } \\
\text { Siwalik residents }(\mathrm{n}=25)\end{array}$} & \multicolumn{3}{c|}{$\begin{array}{c}\text { Radiation-unexposed people } \\
\text { Control group (n=31) }\end{array}$} & $\begin{array}{c}\text { Normal } \\
\text { range }\end{array}$ \\
\cline { 2 - 9 } & Low & High & Total (25) & Low & High & Total (31) & \\
\hline Hemoglobin (g/l) & $10.333(3)$ & $18.30(1)$ & 13.700 & - & - & 15.3548 & $11.5-17.0$ \\
\hline WBC $\left(10^{9} / 1\right)$ & $1.562(4)$ & - & 6.2648 & - & - & 8.0226 & $4.0-11.0$ \\
\hline Platelet count $\left(10^{9} / 1\right)$ & $105.285(7)$ & $524(2)$ & 246.60 & - & - & 253.451 & $(150-400)$ \\
\hline Hematocrit $(\%)$ & $30.423(3)$ & $51.04(2)$ & 42.152 & $34.95(2)$ & $51(2)$ & 42.5452 & $36-50$ \\
\hline RBC $\left(10^{12} / 1\right)$ & $2.75(4)$ & $6.0417(6)$ & 4.8608 & - & $5.766(6)$ & 5.1677 & $3.8-5.5$ \\
\hline Mean cell hemoglobin-MCH (g/l) & $25.138(13)$ & $33(1)$ & 27.276 & $26.857(7)$ & - & 29.2581 & $28-32$ \\
\hline MCH concentration-MCHC (\%) & $31.063(11)$ & $41.2(1)$ & 32.448 & $31.24(5)$ & - & 33.4000 & $32-36$ \\
\hline Lymphocytes-LYM (\%) & $14.7(5)$ & $50.871(7)$ & 33.732 & - & $41.5(4)$ & 32.5484 & $20-40$ \\
\hline Neutrophils-NEUT (\%) & $30.22(5)$ & $83.933(3)$ & 56.992 & - & - & 60.2581 & $40-80$ \\
\hline
\end{tabular}

The column labeled "low" shows mean of the respective CBC parameter below normal range, the column labeled "high" shows mean of the respective $\mathrm{CBC}$ parameter above normal range, and the column labeled "total" shows mean of the respective CBC parameter of each individual. The number in parenthesis describes the number of individuals whose respective $\mathrm{CBC}$ parameter(s) was found to be disturbed (low or high). 
Table 3. The number of radiation-exposed residents expressed in percentages for whose CBC parameters were in either low or high range.

\begin{tabular}{|c|c|c|c|c|}
\hline \multirow{2}{*}{ Parameters } & \multicolumn{2}{|c|}{ Siwalik residents $(n=25)$} & \multicolumn{2}{|c|}{ Control group $(\mathrm{n}=31)$} \\
\hline & Low $\%$ & High $\%$ & Low\% & High $\%$ \\
\hline Hemoglobin-HB (g/l) & 12 & 4 & -- & -- \\
\hline White blood cell-WBC $\left(10^{9} / 1\right)$ & 16 & - & - & - \\
\hline Platelet count-PLT $\left(10^{9} / 1\right)$ & 28 & 8 & - & - \\
\hline Hematocrit-HCT (\%) & 12 & 8 & 6.5 & 6.5 \\
\hline Red blood cells-RBC (10²/l) & 16 & 24 & -- & 19.4 \\
\hline Mean cell hemoglobin-MCH (g/l) & 52 & 4 & 22.6 & - \\
\hline $\mathrm{MCH}$ concentration-MCHC (\%) & 44 & 4 & 16.1 & - \\
\hline Lymphocytes-LYM (\%) & 20 & 28 & - & 12.9 \\
\hline Neutrophils-NEUT (\%) & 20 & 12 & - & - \\
\hline
\end{tabular}

The column labeled "Low\%" indicates the percentage of those people having low values of the respective CBC parameter, whereas the column labeled "High\%" indicates the percentage of those people having high values of the respective CBC parameter.

Table 4. The t-test analysis of significantly differenced mean CBC values between the radiation-exposed resident (RER) and the control group.

\begin{tabular}{|l|c|c|c|c|c|}
\hline \multirow{2}{*}{$\begin{array}{c}\text { Blood } \\
\text { parameters }\end{array}$} & \multicolumn{3}{|c|}{$\mathrm{t}$-test for equality of means } & 95\% Confidence interval (CI) of the difference \\
\cline { 2 - 6 } & $\mathrm{t}$ & $\mathrm{df}$ & $\mathrm{p}$-value & Lower & Upper \\
\hline HB & 4.163 & 31.624 & 0.000 & -2.46489 & -0.84478 \\
\hline WBC & 3.186 & 29.043 & 0.003 & -2.88609 & -0.62947 \\
\hline MCH & 2.749 & 54 & 0.008 & -3.42749 & -0.53663 \\
\hline MCHC & 2.056 & 54 & 0.045 & -1.88032 & -0.02368 \\
\hline HCT (low) & 16.075 & 3 & 0.001 & -5.42283 & -3.63050 \\
\hline LYM (high) & 2.628 & 6.079 & 0.039 & 0.67158 & 18.07128 \\
\hline
\end{tabular}

df - degree of freedom

of RERs had low WBC (mean=1.56) as compared to the controls $(0 \%)$. Also, $28 \%$ of RERs had low PLT (mean $=105.28)$ as compared to the controls $(0 \%)$. Also, $12 \%$ RERs had low HCT (mean=30.42) as compared to the controls $(6.5 \%)$. Also, a significant number (24\%) of RERs had high RBC (mean=6.04) as compared to the controls (19.4\%). Also, 52\% of RERs had low MCH (mean=25.14) as compared to controls (22.6\%). Also, 44\% of RERs had low MCHC (mean=31.06) as compared to the controls (16.1\%). Also, $28 \%$ of RERs had high LYM (mean=50.87) as compared to the controls (12.9\%). And likewise, 20\% RERs had low NUET (mean=30.22) as compared to the controls $(0 \%)$. Overall, seven CBC parameters: HB, WBC, PLT, HCT, MCH, MCHC, and NEUT were mostly below the normal range of radiation-exposed residents and two CBC parameters - RBC and LYM - were mostly in the high range. It is observed, of course, that the majority of the radiation-exposed residents' $\mathrm{CBC}$ parameters were affected because of the long-term exposure from low-dose terrestrial radiation-exposed areas.
Comparisons Based on the t-Tests

between Radiation-Exposed Residents (RER) and Radiation-Unexposed People

Comparisons based on the t-test were conducted to find out $\mathrm{CBC}$ parameters showing the significance of difference between radiation-exposed residents (RER) and radiationunexposed people. The description of t-test (Table 4) shows that significant differences exist in the mean values of $\mathrm{CBC}$ parameters: $\mathrm{HB}, \mathrm{WBC}, \mathrm{MCH}$, and $\mathrm{MCHC}$ between those who were exposed to radiation and those who were not, exposed to radiation. The second t-test shows that significant differences exist in the mean low values of HCT and in the mean high values of the LYM between those who were exposed to radiation and those who were not exposed to radiation.

\section{Odds Ratio and Pearson Chi-Square Test}

Odds ratios were calculated to find out the association of measure between radiation exposure and having an 
Table 5. Risk estimate and Chi-square test results.

\begin{tabular}{|l|c|c|c|c|c|c|}
\hline \multirow{2}{*}{ Parameter } & Odds Ratio for Exposed & \multicolumn{2}{|c|}{$95 \%$ Confidence Interval (CI) } & Pearson Chi-Square & \multirow{2}{*}{ df } & p-value \\
\cline { 2 - 6 } & Value & Lower & Upper & Value & & \\
\hline MCH (low) & 4.052 & 1.266 & 12.970 & 5.832 & 1 & 0.016 \\
\hline MCHC (low) & 4.400 & 1.261 & 15.347 & 5.786 & 1 & 0.016 \\
\hline
\end{tabular}

df - degree of freedom

altered (low or high) CBC parameter. The odds of developing low $\mathrm{MCH}$ were 4.052 times higher and the odds of developing a low MCHC were 4.4 times higher for those who were radiation-exposed as compared to those who were not. The parameters, i.e., $\mathrm{MCH}$ (low) and MCHC (low), were found to be significant at $\mathrm{p}<\alpha=0.050$ (Table 5).

\section{Discussion}

This study was aimed at assessing hematological indices in the people who were residing where naturally occurring radionuclides were present, and hence they were found under the stress of long-term low-level doses of ionizing radiation. These radiation exposures were evident from uranium mineralization. Moreover, a significant number of people were also exposed to radiation from their local professions (laborers or doing agricultural practices). Irradiation of the human body from external radiation sources originates mainly from gamma radiation from terrestrial radionuclides of the ${ }^{238} \mathrm{U}$ and ${ }^{232} \mathrm{Th}$ series, and from ${ }^{40} \mathrm{~K}$ [74]. The ultimate collective effective doses depend on the specific concentration of radionuclides present in the environment and in the human body [75]. It is usually known that higher level exposure to ionizing radiation causes acute tissue injuries, which can lead to organ failure. At lower levels of exposure, though adverse health effects are not immediately observed, there is a possibility of their late appearance [76]. Soluble uranium is a potential radiotoxic and the population may be exposed to even low levels through inhalation and from drinking water [77, 78]. Uranium can mix into the drinking water supply during mining processes [76]. A cohort study was done in Finland on people having uranium contaminated water from drilled wells. It was found that uranium can accumulate in the bones and kidneys [79].

The hematopoietic system endures energy in mammals and includes bone marrow, which is the main blood-forming system [1-5]. Blood-forming cells are located in bone marrow, and these are highly vulnerable to radiation damage $[1,6-8,13,32,64]$. Rapidly dividing bone marrow cells are more prone to ionizing radiation. These precursor cells in bone marrow differentiate into different cell lines and are designed to perform various functions once they reach maturity and are dispersed into the blood stream. Human immune response is dependent on the potential actions performed by lymphocytes and granulocytes arising from the bone marrow, and function in the blood stream. The lym- phocytes are more radiosensitive than platelets, which are relatively radioresistant. The similar effects of ionizing radiation on the hematopoietic system explain the lowering of peripheral blood counts $[1,64,80]$. The severities of health issues that may arise from ionizing radiation are dependent on effective radiation doses and exposure time [81].

The bone marrow system is highly radiosensitive and therefore analysis of the hematopoietic system for radiationexposed people is emphasized. It is found in this study that radiation-exposed people's blood parameters were more altered as compared to the radiation unexposed people. The radiation to which they were exposed were low (i.e., 0.4383$1.3149 \mathrm{mSv} / \mathrm{y}$ ), but hematological abnormalities were observed. It has also been reported that long-term exposure, even to low doses, can be harmful and induce significant adverse health effects. The mean value of the environmental gamma radiation dose rate level in Pakistan is $59 \mathrm{nGy} / \mathrm{h}$, which is higher than the worldwide mean value of $44 \mathrm{nGy} / \mathrm{h}$ as reported in UNSCEAR (1988) [32, 81-83].

We are naturally exposed to terrestrial radionuclides present in the environment. Furthermore, radioactively contaminated building material can gather radon gas inside houses [32, 82]. Residents from Siwalik regions exposed to radioactivity are considered under the stress of uranium effects. Elevated levels of uranium deposits can have adverse impacts on DNA since it has a high affinity with DNA [84]. Uranium particles can attach to the DNA and can intensify the impacts from ionizing radiations by the phenomenon of photoelectron enhancement effect $[32,85]$. It is evident that sustained and continued radiation exposure from the environment can pose substantial health threats to populations. Health risks of radon were mentioned by the Committee on the Biological Effects of Ionizing Radiation (BEIR) within the U.S. National Research Council (BEIR), and it was declared that radon is a cause of lung cancer in humans. Hematopoietic lesions in uranium miners have also been studied in some cohort studies [86, 87].

Depleted uranium and natural uranium are environmental pollutants that emerge from uranium-rich regions [8790]. They are regarded as radiological hazards [87]. Some epidemiological studies have provided evidence that an excess risk of cardiovascular diseases may also be associated with low-dose radiation [76]. Uranium mining has been linked to human cancers. It was mentioned in a report that depleted uranium compounds cause human cell transformation to the neoplastic phenotype [92]. A paper has mentioned many studies related to reproductive toxicity in 
humans and animals from uranium or depleted uranium exposure [93]. There are risks associated with long-term exposure from dusty particles of depleted uranium, and its drinking water contamination can lead to damaged lungs, kidneys, and brain [63, 79, 88, 89, 94-99].

This study reported that $92 \%$ of radiation-exposed dwellers were not taking ionizing radiation-free drinking water. Terrestrial radionuclides, which decay relatively more slowly, can accumulate in human body tissues [21]. The high concentration of radon gas escaping from the soil can accumulate in buildings and thereby lead to poor indoor quality [99]. Radiation exposure at low to moderate doses may increase the long-term incidence of cancer. In the Dera Ismail Khan District, Pakistan, indoor radon levels were found to vary from $70-222 \mathrm{~Bq} \cdot \mathrm{m}^{-3}$, with an average value of $139 \pm 23 \mathrm{~Bq} \cdot \mathrm{m}^{-3}[100]$. The mean annual indoor effective dose ranged from $2.22-17.44 \mathrm{mSv}^{\cdot} \mathrm{yr}^{-1}$, with an average of $8.68 \mathrm{mSv} \cdot \mathrm{yr}^{-1}$ in nearby regions of Dera Ghazi Khan District [100]. The impact of environmental agents, notably ionizing radiation, has been tested on a variety of cells, including lymphocytes, bone marrow cells, spermatocytes, and fibroblasts [101].

Overall, seven $\mathrm{CBC}$ parameters - HB, WBC, PLT, $\mathrm{HCT}, \mathrm{MCH}, \mathrm{MCHC}$, and NEUT - were found below the normal range, and two $\mathrm{CBC}$ parameters - RBC and LYM were found above the normal range. It has been observed, of course, that the majority of these radiation residents had their CBC parameters affected because of their long-term dwelling in the terrestrial radiation-exposed areas. The four most affected $\mathrm{CBC}$ parameters were $\mathrm{MCH}, \mathrm{MCHC}$, PLT, and LYM in radiation-exposed residents. It is concluded here that most of the $\mathrm{CBC}$ parameters were altered by lowdose radiation exposure. The results indicate that radiation induces anemia and modulates the immune response. Radiation-induced immunosuppression is an important aspect to study for the radiation exposed populations. Ionizing radiations deplete hematopoietic stem and progenitor cells and can decrease granulocytes, lymphocytes, and platelets, and people may be vulnerable to infections [61, 64]. These radiation-exposed dwellers may compromise their immunity, pre-aging and longevity, etc., as well [102, 103]. Low-dose irradiations are found to affect immune system functions and cells. Individuals occupationally exposed to long-term ionizing radiation have shown immunocompromising effects [103]. It is reported that radiation exposure induces acute/chronic immunodeficiency in humans $[104,105]$. Ionizing radiation influence is followed by alterations in the immune system at cellular levels and secondary immunodeficiency [106]. Exposure to ionizing radiation can further initiate other forms of abnormalities from a depressed immune system $[102,107]$.

Although higher doses of ionizing radiation can suppress the immune system, low doses can also modulate the immune system. Various studies were carried out to assess the effects of high background radiation on the immune system [36]. A stimulated response induced by exposure to low-dose radiation is also reported [108]. The immune-suppressive effects are reported from high doses of radiation, but it is also reported that long-term exposure to low-dose radiation can also alter immune response by the destruction of certain cell types [109].

A majority of radiation-exposed people suffer from lower levels of $\mathrm{MCH}$ and $\mathrm{MCHC}$. Effects of ionizing radiations have been observed through decreasing trends in $\mathrm{MCH}$ and $\mathrm{MCHC}$ levels, and an increasing trend in lymphocytes and RBC levels. Increased RBC levels have also been identified in a study in which irradiated human blood samples from Radium-226 source were analyzed through CBC reports [110]. Previous studies show that radiation can induce an anemic condition followed by radiation-induced hypoxemia, which can provoke higher production of red blood cells. Ionizing radiation has deleterious effects on cellular growth and can affect programmed cell death. Observation of CBC parameters conclude that a decline in the mature white cells in peripheral blood was in part due to increased reticulocyte production as a result of hypoxia in the bone marrow. This leads to a rise in proliferation of red blood cells and failure to attain maturity before spilling out the bone marrow into the blood stream. The counts of the reticulocytes (immature red blood cells) increase, and a relative reduction of mature red blood cells occurs within the bone marrow. This is also reflected in the peripheral picture.

A similar immaturity of white blood cells becomes prominent and causes the immunity to be depressed due to the lesser potency of immature white blood cells. A subsequent restorative mechanism may also be initiated in the bone-marrow afterward [64, 111]. Lymphocytes have been found to be the most radiosensitive cells [111, 112]. At lower doses, ionizing radiation can affect the immune system by suppressing or stimulating it [17]. Therefore, ionizing radiation can modulate the immune system. The immune system has an important function related to the exposure of ionizing radiation and it can either show a rise or a decline. As lymphocytes are highly radiosensitive, the immune system is found vulnerable to ionizing radiation $[17,64,113]$. It has been observed that long-term exposure from ionizing radiation can affect the immune system even at lower doses of radiation [17, 64, 114-117]. Granulocyte cells are largely involved in immune response, which includes neutrophils and macrophage. The response of these cells is inflammation, because granulocytes gather at the location of infection and they release toxic substances to kill hostile agents. Macrophages release cytokines, which have useful effects during fever and wound healing, etc. The receptors of lymphocytes on each cell disposed with an antigen on the hostile and these antigen-specific cells when activated, divide to produce cell populations by the process of proliferative response [118-120].

Ionizing radiation exposure induces suppressed response to the circulating hematopoietic, which can lead to the apoptosis of mature cells of the blood $[64,111]$. A study indicated that the mean of total white blood cells was significantly decreased in exposed workers as compared to the controls [113]. In a study it was found that the levels of CD4+ $\mathrm{T}$ lymphocytes in a radiation-exposed group were significantly lower as compared to the controls [113]. Increased health risk of the workers exposed to small but 
persistent doses of ionizing radiations from their profession as well as from the contaminated environment by depleted uranium has radiobiological effects [121]. Similarly, a study was conducted to analyze blood count parameters of the people who were residing and working in terrain where low levels of ionizing radiation doses were present [122]. Reduction in hematopoietic stem cells' re-constitutive capacity depends on absorbed doses [32, 123-125]. Several studies have reported higher occurrences of malignancies in the hematopoietic system in response to ionizing radiation exposure [61]. A study found that bone marrow can be damaged from radiation exposure. The sub-lethal doses can cause a deficit to the bone marrow microenvironment, and thereby a decline in hematopoietic cells [109].

\section{Conclusions}

This study focuses the impacts of low-dose long-term natural terrestrial ionizing radiation exposure on the hematopoietic indices on Siwalik inhabitants in Pakistan. The hematopoietic system is vulnerable to long-term exposure from low-dose radiation. Most of the radiation-exposed inhabitants' CBC parameters were observed suppressed. Most affected $\mathrm{CBC}$ parameters found low and these were: MCH (52\%), MCHC (44\%), and PLT (28\%). The most affected CBC parameter found to be high was LYM (28\%). Seven CBC parameters - HB, WBC, PLT, HCT, MCH, $\mathrm{MCHC}$, and NEUT - have shown a decreased trend in radiation-exposed residents and two CBC parameters - RBC and LYM - have shown an increased trend. The majority of the radiation-exposed residents had their $\mathrm{CBC}$ parameters affected because of their long-term low-dose exposure from terrestrial radiation-exposed areas. Significant differences were found in the $\mathrm{HB}, \mathrm{WBC}, \mathrm{MCH}, \mathrm{MCHC}, \mathrm{HCT}$ (low), and LYM (high) parameters by the t-tests between those exposed to radiation and those not exposed to radiation. Most of the CBC parameters have been altered by the radiation and mostly were found in the lower range. Radiationinduced anemia and immune modulations is inferred in these radiation-exposed people. Radiation-induced immunosuppression is an important aspect to study for the radiation-exposed populations, as these radiation-exposed dwellers may compromise their immunity.

The safety measures should be kept in mind for such inhabitants to save them from any radiation exposure. The adverse effects of ionizing radiation exposure on the immune response of the organisms are well reported. It is suggested that exposed inhabitants should be made aware of the importance of regular medical checkups, especially for immune response. We suggest that there should be monitoring for the pursuit of those water springs or aquifers whose flow can provide safe drinking water free from uranium minerals. The indoor radon exposure levels could be minimized by reconsidering the architecture of the houses and buildings. Moreover, special plantation could be considered which shows the capability to gather and store uranium particles in the roots, so that uranium becomes less available to living beings [32].

\section{Acknowledgements}

This research was supported by a grant from the Higher Education Commission (HEC), Islamabad, Pakistan and the University of the Punjab, Lahore Pakistan. We are thankful to Dr. Aziz Ullah, (chief scientist, Pakistan Atomic Energy Commission (PAEC), Islamabad), who provided the radiation measurements from the scintillation detector.

\section{References}

1. SMIRNOVA O. A. Environmental radiation effects on mammals, Springer. 2010.

2. $\quad$ SHIN S.C., LEE K.M., KANG Y.M., KIM K., KIM C.S., YANG K.H., JIN Y.W., KIM C.S., KIM H.S. Alteration of cytokine profiles in mice exposed to chronic low-dose ionizing radiation. Biochem. Bioph. Res. Co. 397, 644, 2010.

3. LITTLE M.P., WAKEFORD R., LUBIN J.H., KENDALL G.M. The statistical power of epidemiological studies analyzing the relationship between exposure to ionizing radiation and cancer, with special reference to childhood leukemia and natural background radiation. Radiat. Res., 174, 387, 2010.

4. FLIEDNER T. M., GRAESSLE D. H., MEINEKE V., FEINENDEGEN L. E. Hemopoietic response to low doserates of ionizing radiation shows stem cell tolerance and adaptation. Dose-Response, 10, 644, 2012.

5. FLIEDNER T.M., GRAESSLE D.H. Hematopoietic cell renewal systems: mechanisms of coping and failing after chronic exposure to ionizing radiation. Radiat. Environ. Bioph. 47, 63, 2008.

6. MUNKER R., HILLER E., GLASS J., PAQUETTE R. Modern hematology, Springer 2007.

7. YOUNG N. S., GERSON S. L., HIGH, K. A. Clinical hematology, Elsevier Health Sciences. 2006.

8. LITTLE M.P., AZIZOVA T.V., BAZYKA D., BOUFFLER S.D., CARDIS E., CHEKIN S., VADIM V.C., CUCINOTTA F.A., DE VATHAIRE F., HALL P., HARRISON J.D., HILDEBRANDT G., IVANOV V., VALERIY V.K., KLYMENKO S.V., KREUZER M., LAURENT O., OZSAZA K., SCHNEIDER T., TAPIO S., TAYLOR A.M., TZOULAKI I., VANDOOLAEGHE W.L., WAKEFORD R., ZABLOTSKA L.B., ZHANG W., LIPSHULTZ S.E. Systematic review and meta-analysis of circulatory disease from exposure to low-level ionizing radiation and estimates of potential population morality risks. Environ. Health. Persp. 120, 1503, 2012.

9. LEWIS R. Cell and Molecular Biology: Human Genetics: Concepts and Applications. McGraw-Hill USA. 2009.

10. ANNALS OF THE ICPR. Early and late effects of radiation in normal tissues and organs: threshold doses for tissue reactions and other non-cancer effects of radiation in a radiation protection context. www.icrp.org. 2012.

11. McGEOGHEGAN D., BINKS K., GILLIES M., JONES S., BHATTI W.S. The non-cancer mortality experience of male workers at British Nuclear Fuels plc, 1946-2005. Int. J. Epidemiol., 37, 506, 2008.

12. AMUNDSON S.A. Functional genomics and a new era in radiation biology and oncology. Bioscience. 58, 491, 2008.

13. EDWARDS G. Health and Environmental Issues Linked to the Nuclear Fuel Chain. Canadian Environmental Advisory Council. Retrieved from: http://www.ccnr.org/ceac_A.html 1997. 
14. JIBIRI N. Assessment of health risk levels associated with terrestrial gamma radiation dose rates in Nigeria. Environ. Int., 27, 21, 2001.

15. National Toxicology Program (NTP). Report on Carcinogens. US Dept. of Health and Human Services, Public Health Service, 12, 239-244, 2011.

16. AHAD A., UR REHMAN S., UR REHMAN S., FAHEEM M. Measurement of radioactivity in the soil of Bahawalpur division, Pakistan. Radiat. Prot. Dosim., 112, 443, 2004

17. UNSCEAR. United Nations Scientific Committee on the effects of atomic radiation, vol. I. New York: United Nations. 2008

18. WILSON J. W. Overview of radiation environments and human exposures. Health Phys., 79, 470, 2000.

19. RAFIQUE M., RAHMAN S.U., JABEEN S., IKRAM M., RAHMAN S., BUKHARI S., NASIR T., MATIULLAH. Measurement and comparison of indoor radon levels in new and old buildings in the city of Muzaffarabad (Aazad Kashmir), Pakistan: a pilot study. Radioisotopes (Japan), 58, 749, 2009.

20. NAIR R. R. K., RAJAN B., AKIBA S., JAYALEKSHMI P., NAIR M. K., GANGADHARAN P., KOGA T., MORISHIMA H., NAKAMURA S., SUGAHARA T. Background radiation and cancer incidence in Kerala, IndiaKaranagappally cohort study. Health Phys., 96, 55, 2009.

21. WAHL LE. Environmental Radiation-A Fact Sheet. Health Physics Society, Lawrence: Berkeley National Laboratory. Retrieved from: http://hps.org/hpspublications/radiationfactsheets.html 2010.

22. TUFAIL M., AKHTAR N., WAQAS M. Measurement of terrestrial radiation for assessment of gamma dose from cultivated and barren saline soils of Faisalabad in Pakistan. Radiat. Meas., 41, 443, 2006

23. ROESSLER C., SMITH Z., BOLCH W., PRINCE R. Uranium and radium-226 in Florida phosphate materials. Health Phys., 37, 269, 1979.

24. MERKEL B., HASCHE-BERGER A. Uranium, mining and hydrogeology, Springer. 2008.

25. DE KOK L. J., FLECKENSTEIN J. Loads and fate of fertilizer-derived uranium, Margraf. 2008.

26. AL-MUQDADI K., AL-ANSARI N. Depleted uranium: Its nature, characteristics and risks of the military uses on humans and the environment. Workshop on Landfills of Hazardous Waste and Its Implications on Health and Environment. 2011.

27. SHAH S. I. Stratigraphy of Pakistan, Government of Pakistan Ministry of Petroleum \& Natural Resorces Geological Survey of Pakistan. 2009.

28. KHAN F., ALI N., KHAN E.U., KHAN N.U., KHATTAK N.U., KHAN K. Radon monitoring in water sources of Balakot and Mansehra cities lying on a geological fault line. Radit. Prot. Dosim. 138, 174, 2010.

29. CHAUDHARY M., HUSSAIN K., SHAH M. Petrology of Dhok Pathan Formation, Swaliks Group of Kalabagh and Mangla Areas. Geol. Bull. Punjab Univ, 20, 24, 1985.

30. KHAN I.A., BRIDGE J.S., KAPPLEMAN J., WILSON R. Evolution of Miocene fluvial enrichment in eastern Potwar plateau, northern Pakistan. Sedimentology, 44, 221, 1997.

31. DAHLKAMP F. J. Uranium deposits of the world, Springer. 2009.

32. SHAHID S., CHAUDHRY M.N., MAHMOOD N., SHEIKH S. Mutations of the human interferon alpha- $2 b$ gene in brain tumor patients exposed to different environmental conditions. Cancer Gene Ther. 22, (5), 246, 2015. doi:10.1038/cgt.2015.12.
33. NASIR T., SHAH M. Measurement of Annual Effective Doses of Radon from Drinking Water and Dwellings by CR39 Track Detectors in Kulachi City of Pakistan. Journal of Basic \& Applied Sciences. 8, 528, 2012.

34. MOGHAL M. Exploration of uranium deposits in Dera Ghazi Khan District (Punjab), Pakistan. Geol. Surv. Pak. Geonews, 5, 72, 1974.

35. CHAUDHRY M. N., GHAZANFAR M. Position of the Main Central Thrust in the tectonic framework of Western Himalaya. Tectonophysics, 174, 321, 1990.

36. GHIASSI-NEJAD M., MORTAZAVI S., CAMERON J., NIROOMAND-RAD A., KARAM P. Very high background radiation areas of Ramsar, Iran: preliminary biological studies. Health Phys., 82, 87, 2002.

37. MOMČILOVIĆ M., KOVAČEVIĆ J., DRAGOVIĆ S. Population doses from terrestrial exposure in the vicinity of abandoned uranium mines in Serbia. Radiat. Meas., 45, 225, 2010.

38. AZIZ ULLAH. Petrotectonice, petrology and genesis of uranium mineralization of the siwalik group of Thatti Nasrati and Shahvah-Shanawa area. Ph.D. Thesis, Institute of Geology, University of the Punjab, Lahore. 1997.

39. CHAREYRON B. Radiological hazards from uranium mining. Uranium, Mining and Hydrogeology. Springer. 2008.

40. MERKEL B., PLANER-FRIEDRICH B., WOLKERSDORFER C. Uranium in the Aquatic Environment: proceedings of the International Conference [on] Uranium Mining and Hydrogeology III and the International Mine Water Association Symposium, Freiberg, Germany, 15-21 September. Springer. 2002.

41. OELOFSE S. Mine water pollution-acid mine decant, effluent and treatment: a consideration of key emerging issues that may impact the state of the environment. 2009.

42. KOHRS B. Earthlife's concerns regarding uranium mining in Namibia in Roan News. Special Edition on Uranium Mining and Mining in Parks, Namibian Environment \& Wildlife Society, 19-21, 2008.

43. MOSER M., LEO O. Key concepts in immunology. Vaccine. 28, C2, 2010.

44. GRAHN D., KRATCHMAN J. Variation in neonatal death rate and birth weight in the United States and possible relations to environment radiation, geology and altitude. Am. J. Hum. Genet., 15, 329, 1963.

45. KNOLLE F., SCHNUG E., BIRKE M., HASSOUN R., JACOBS F. Uranium in German mineral water-occurrence and origins. The New Uranium Mining Boom: Springer; pp. 749-54, 2012.

46. SCHNUG E, HANEKLAUS S. Dispersion of uranium in the environment by fertilization. Uranium, Mining and Hydrogeology: Springer; pp. 45-52, 2008.

47. KRAT S, SCHNUG E. Rock phosphates and P fertilizers as source of U contamination in agricultural soils, in Merkel B.J. \& Hasche-Berger A. (Eds.) Uranium in the Environment, Mining Impacts and Consequences, Springer-Verlag Berlin Heidelberg 2006, ISBN 13 978-3-540-28363-8. 2006.

48. LINDEMANN I. Hazards of Uranium, paper was presented in workshops of the Labour Resource and Research Institute (LaRRI) and Earthlife Namibia, both located in Windhoek. Swakopmund and Arandis October $25^{\text {th }}$ till November $1^{\text {st }}$, 2008.

49. MA Y., CONFORTI R., AYMERIC L., LOCHER C., KEPP O., KROEMER G., ZITGOVEL L. How to improve the immunogenicity of chemotherapy and radiotherapy. Cancer Metast. Rev. 30, 71, 2011. 
50. TOMÁŠEK L., KUNZ E., DARBY S., SWERDLOW A., PLACEK V. Radon exposure and cancers other than lung cancer among uranium miners in West Bohemia. The Lancet, 341, 919, 1993.

51. WANG Y., SCHEIBER M.N., NEUMANN C., CALIN G.A., ZHOU D. MicroRNA regulation of ionizing radiationinduced premature senescence. Int. J. Radiat. Oncol. Biol. Phys. 81, 93, 2011.

52. TOUIL N., AKA P. V., BUCHET J.-P., THIERENS H., KIRSCH-VOLDERS M. Assessment of genotoxic effects related to chronic low level exposure to ionizing radiation using biomarkers for DNA damage and repair. Mutagenesis, 17, 223, 2002.

53. GARAJ-VRHOVAC, V., KOPJAR N. The alkaline Comet assay as biomarker in assessment of DNA damage in medical personnel occupationally exposed to ionizing radiation. Mutagenesis, 18, 265, 2003.

54. KOPJAR N., GARAJ-VRHOVAC V. Assessment of DNA damage in nuclear medicine personnel-comparative study with the alkaline comet assay and the chromosome aberration test. Int. J. Hyg. Envir. Heal., 208, 179, 2005.

55. ARENS R., SCHOENBERGER S.P. Plasticity in programming of effector and memory CD8 T-cell formation. Immunol. Rev. 235, 190, 2010.

56. BUTTERWORTH K.T., McMAHON S.J., HOUNSELL A.R., O'SULLIVAN J.M. Bystander signaling: exploring clinical relevance through new approaches and new models. Clin. Oncol. 25, 582, 2013.

DOI: http://dx.doi.org/10.1016/j.clon.2013.06.005

57. DUPREE-ELLIS E., WATKINS J., INGLE J. N., PHILLIPS J. External radiation exposure and mortality in a cohort of uranium processing workers. Am. J. Epidemiol., 152, 91, 2000.

58. PINKERTON L., BLOOM T., HEIN M., WARD E. Mortality among a cohort of uranium mill workers: an update. Occup. Environ. Med., 61, 57, 2004.

59. CANU I. G., ELLIS E. D., TIRMARCHE M. Cancer risk in nuclear workers occupationally exposed to uranium Emphasis on internal exposure. Health Phys., 94, 1, 2008

60. VAKIFAHMETOGLU H., OLSSON M., ZHIVOTOVSKY B. Death through a tragedy: mitotic catastrophe. Cell Death Differ., 15, 1153, 2008.

61. MILLER A.C. Late and low-level effects of ionizing radiation In Medical consequences of radiological and nuclear weapons. Eds. Anthony B. Mickelson MD, Borden Institute, Patricia D. Horoho, pp. 195-215, 2013.

62. MANDA K., KAVANAGH J. N., BUTTLER D., PRISE K. M., HILDEBRANDT G. Low dose effects of ionizing radiation on normal tissue stem cells. Mutation Research/Reviews in Mutation Research. 2014.

63. RODEL F., FREY B., GAIPL U., KEILHOLZ L., FOURNIER C., MANDA K., SCHOLLNBERGER H., HILDEBRANDT G., RODEL C. Modulation of inflammatory immune reactions by low-dose ionizing radiation: molecular mechanisms and clinical application. Curr. Med. Chem., 19, 1741, 2012.

64. SHAHID S., CHAUDHRY M.N., MAHMOOD N., SHEIKH S., NAUMAN A. Assessment of impacts of hematological parameters of chronic ionizing radiation exposed workers in hospitals. Fuuast J. Biol. 4, (2), 135, 2014.

65. SAWANT S., RANDERS-PEHRSON G., GEARD C., BRENNER D., HALL E. The bystander effect in radiation oncogenesis: I. Transformation in $\mathrm{C} 3 \mathrm{H} 10 \mathrm{~T}^{1} / 2$ cells in vitro can be initiated in the unirradiated neighbors of irradiated cells. 2009.
66. AKLEYEV A.V. Chronic radiation syndrome, SpringerVerlag Berling Heidelberg. 2014. DOI 10.1007/978-3-64245117_3

67. BASKAR R., LEE K.A., YEO R., YEOH K.W.U. Cancer and radiation therapy: current advances and future directions. Int. J. Med. Sci. 9, 193, 2012.

68. AINSBURY E. A., BOUFFLER S. D., DÖRR W., GRAW J., MUIRHEAD C. R., EDWARDS A. A., COOPER J. Radiation Cataractogenesis: A Review of Recent Studies. Radiat. Res., 172, 1, 2009.

69. SCHMID E., SCHRADER T. Different biological effectiveness of ionising and non-ionising radiations in mammalian cells. Advances in Radio Science, 5, 1, 2007.

70. BARCELLOS-HOFF M. H., ADAMS C., BALMAIN A., COSTES S. V., DEMARIA S., ILLA-BOCHACA I., MAO J. H., OUYANG H., SEBASTIANO C., TANG J. Systems biology perspectives on the carcinogenic potential of radiation. J. Radiat. Res., 55, i145, 2014.

71. SHIMIZU Y., KODAMA K, NISHI N, KASAI F., SUYAMAA., SODA M, GRANT E.J., SUGIYAMA H., SAKATA R., MORIWAKI H., HAYASHI M., KONDA M., SHORE R.E. Radiation exposure and circulatory disease risk: Hiroshima and Nagasaki atomic bomb survivor data, 19502003. BMJ 340, b54349, 2010.

72. AKLEYEV A.V., AKUSHEVICH I.V., DIMOV G.P., VEREMEYEVA G.A., VARFOLOMEYEVA T.A., UKRAINTSEVA S.V., YASHIN A.I. Early hematopoitsis inhibition under chronic radiation exposure in humans. Radiat. Environ. Bioph., 49, 281, 2010.

73. MEHDI T., MUSTAFA T., CHAUDHRY R., BUTT S., HOAT A., ALI M., AMIN K., TARIQ S. Profile of district Dera Ismail khan with focus on livelihood related issues. Published by South Asia Partnership-Pakistan. 2009.

74. TANIĆ M. N., MOMČILOVIĆ M. Z., KOVAČEVIĆ J. R., DRAGOVIĆ S. D., BAČIĆ G. G. Assessment of radiation exposure around abandoned uranium mining area of Stara planina Mt., Serbia. Nuclear Technology and Radiation Protection, 29, 58, 2014.

75. HILDEBRANDT G. Non-cancer disease and non-targeted effects. Mutat. Res. 687, 73, 2010.

76. BORGHINI A., LUCA GIANICOLO E. A., PICANO E., ANDREASSI M. G. Ionizing radiation and atherosclerosis: Current knowledge and future challenges. Atherosclerosis, 230, 40, 2013.

77. DOMINGO J. L. Reproductive and developmental toxicity of natural and depleted uranium: a review. Reprod. Toxicol., 15, 603, 2001.

78. ZAMORA M. L., TRACY B., ZIELINSKI J., MEYERHOF D., MOSS M. Chronic ingestion of uranium in drinking water: a study of kidney bioeffects in humans. Toxicol. Sci., 43, 68, 1998.

79. KURTTIO P., KOMULAINEN H., LEINO A., SALONEN L., AUVINEN A., SAHA H. Bone as a possible target of chemical toxicity of natural uranium in drinking water. Environ. Health Persp. 68-72, 2005.

80. DEPARTMENTS OF THE ARMY, THE NAVY, AND THE AIR FORCE. NATO Handbook on the Medical Aspects of NBC Defensive Operations. 1966; Available at: http://www.fas.org/nuke/guide/usa/doctrine/dod/fm8-9/toc.htm

81. BUTT K. A., ALI A., QURESHI A. A. Estimation of environmental gamma background radiation levels in Pakistan. Health Phys., 75, 63, 1998.

82. NAKATSUKAS H., TSUKIMOTO M., TOKUNAGA A., KOJIMA S. Repeated gamma irradiation attenuates collagen-induced arthritis via upregulation of regulatory T cells 
but not by damaging lymphocytes directly. Radiat. Res. 174, 313, 2010

83. United Nations Scientific Committee on the Effects of Atomic Radiations. Sources, effects and risks of ionising radiation. New York: United Nations; 1988.

84. HENNER P. Bioaccumulation of radionuclides and induced biological effects in situations of chronic exposure of ecosystems a uranium case study. In: De Kok LJ Schnug E, Eds. Loads and fate of fertilizer-derived uranium. Netherlands: Backhuys Publishers, 23-31, 2008.

85. BUSBY C., SCHNUG E. Advanced biochemical and biophysical aspects of uranium contamination. Loads and Fate of Fertilizer Derived Uranium, LJ DeKok \& E Schnugg ed., Backhuys Publishers, Leiden, Netherlands. 2007.

86. ELLETT W. H. The BEIR IV Report. Radiat. Res., 116, 173, 1988.

87. SEVC J., KUNZ E., PLACEK V. Lung cancer in uranium miners and long-term exposure to radon daughter products. Health Phys., 30, 433, 1976.

88. BRINER W. The toxicity of depleted uranium. International Journal of Environmental Research and Public Health, 7, 303, 2010

89. CRAFT E. S., ABU-QARE A. W., FLAHERTY M. M., GAROFOLO M. C., RINCAVAGE H. L., ABOU-DONIA M. B. Depleted and natural uranium: chemistry and toxicological effects. J. Toxicol. Env. Heal. B, 7, 297, 2004.

90. SQUIBB K. S., GAITENS J. M., ENGELHARDT S., CENTENO J. A., XU H., GRAY P., MCDIARMID M. A. Surveillance for long-term health effects associated with depleted uranium exposure and retained embedded fragments in US veterans. J. Occup. Environ. Med., 54, 724, 2012.

91. PRANJIĆ N., KARAMEHIĆ J., LJUCA F., ZIGIĆ Z., ASCERIĆ M. Internal contamination with depleted uranium and health disorders. Medicinski arhiv, 56, 39, 2001.

92. PUSKIN J.S. Perspective on the use of LNT for radiation protection and risk assessment by the U.S. Environmental Protection Agency. Dose Response, 7, 284, 2009.

93. ARFSTEN D. P., STILL K. R., RITCHIE G. D. A review of the effects of uranium and depleted uranium exposure on reproduction and fetal development. Toxicol. Ind. Health, 17, 180, 2001

94. BLEISE A., DANESI P., BURKART W. Properties, use and health effects of depleted uranium (DU): a general overview. J. Environ. Radioactiv., 64, 93, 2003.

95. JIANG G. C.-T., ASCHINER M. Neurotoxicity of depleted uranium. Biol. Trace Elem. Res., 110, 1, 2006.

96. KURTTIO P., HARMOINEN A., SAHA H., SALONEN L., KARPAS Z., KOMULAINEN H., AUVINEN A. Kidney toxicity of ingested uranium from drinking water. Am. J. Kidney Dis., 47, 972, 2006.

97. MCCLAIN D. E., BENSON K. A., DALTON T. K., EJNIK J., EMOND C. A., HODGE S. J., KALINICH J. F., LANDAUER M. R., LIVENGOOD D. R., MILLER A. C. Health effects of embedded depleted uranium. Mil. Med., 167, 117, 2002.

98. OTANI A., KOJIMA H., GUO C., OISHI A., YOSHIMURA N. Low-dose-rate, low-dose irradiation delays neurodegeneration in a model of retinitis pigmentosa. Am. J. Pathol., 180, 328, 2012.

99. NASIR T., ADIL M. A Preliminary Study on Indoor Radon Measurements in some mud made houses in the outskirts of Dera Ismail Khan City of Pakistan. Nucleus, 50, 273, 2013.

100. MALIK F., RAFIQUE M. Indoor radon monitoring near an in situ leach mining site in D G Khan, Pakistan. Journal of Radiological Protection, 32, 427, 2012
101. HUMAN MORTALITY DATABASE. University of California at Berkeley, Max Planck Institute for Demographic Research. 2009.

102. KUSUNOKI Y., HAYASHI T. Long-lasting alterations of the immune system by ionizing radiation exposure: implications for disease development among atomic bomb survivors. Int. J. Radiat. Biol., 84, 1, 2008.

103. RICHARDSON R. B. Ionizing radiation and aging: rejuvenating an old idea. Aging (Albany NY), 1, 887, 2009.

104. KYOIZUMI S., UMEKI S., AKIYAMA M., HIRAI Y., KUSUNOKI Y., NAKAMURA N., ENDOH K., KONISHI J., SASAKI M. S., MORI T. Frequency of mutant T lymphocytes defective in the expression of the T-cell antigen receptor gene among radiation-exposed people. Mutation Research/Fundamental and Molecular Mechanisms of Mutagenesis, 265, 173, 1992.

105. AKLEYEV A.V. Mechanisms involved in chronic radiation exposure effects: pathogenesis of chronic radiation syndrome. Chronic Radiation Syndrome, 2014, 55-129, 2013.

106. KIRILLOVA E., ZAKHAROVA M., LUKIANOVA T., LOFFREDO C. $2^{\text {nd }}$ International Conference on Clinical \& Cellular Immunology. Immunology, 2013.

107. KUZMENOK O., POTAPNEV M., POTAPOVA S., SMOLNIKOVA V., RZHEUTSKY V., YARILIN A. A., SAVINO W., BELYAKOV I. M. Late effects of the Chernobyl radiation accident on $\mathrm{T}$ cell-mediated immunity in cleanup workers. 2009.

108. RODEL F., HOFMANN D., AUER J., KEILHOLZ L., ROLLINGHOFF M., SAUER R., BEUSCHER H.U. The anti-inflammatory effect of low-dose radiation therapy of involves a diminished CCL20 chemokine expression and granulocyte/endothelial cell adhesion. Strahlenther, Onkol. 184, 41, 2008.

109. GREEN D. E., RUBIN C. T. Consequences of irradiation on bone and marrow phenotypes, and its relation to disruption of hematopoietic precursors. Bone, 63, 87, 2014.

110. ISMAIL A. H., JAAFAR M. S. Interaction of low-intensity nuclear radiation dose with the human blood: Using the new technique of CR-39NTDs for an in vitro study. Appl. Radiat. Isotopes, 69, 559, 2011.

111. DAINIAK N. Hematologic consequences of exposure to ionizing radiation. Exp. Hematol., 30, 513, 2002.

112. ALI N., KHAN E.U., AKHTER P. KHAN F., WAHEED A. Estimation of mean annual effective dose through radon concentration in the water and indoor air of Islamabad and Murree. Radiat. Prot. Dosim. 141, (2), 183, 2010.

113. CACIARI T., CAPOZZELLA A., TOMEI F., NIETO H., GIOFFRÈ P., VALENTINI V., SCALA B., ANDREOZZI G., DE SIO S., CHIGHINE A. Professional exposure to ionizing radiations in health workers and white blood cells. Annali di igiene: medicina preventiva e di comunita, 24, 465, 2011.

114. DONNELLY E.H., NEMHAUSER J.B., SMITH J.M., KAZZI Z.N., FARFAN E.B., CHANG A.S., NAEEMM S.F. Acute radiation syndrome: assessment and management. South Med. J. 103, 541, 2010.

115. KŁUCIŃSKI P., MAZUR B., KAUFMAN J., HRYCEK A., CIEŚLIK P., MARTIROSIAN G. Assessment of blood serum immunoglobulin and C-reactive protein concentrations in workers of $\mathrm{X}$-ray diagnostics units. International journal of occupational medicine and environmental health, 18, 327, 2005.

116. ZYKOVA I., SOKOLOVA N., IAS'KOVA V. Characteristics of peripheral blood leukocytes in persons working with ionizing radiation sources. Meditsinskaia radiologiia, 29, 58, 1984. 
117. SOLDATOV S., USHAKOV I. Low doses of ionizing radiation and short-and long-term hematologic changes (review of the literature). Meditsina truda i promyshlennaia ekologiia, 20-23, 1994

118. FORMENTI S.C. Immunological aspects of local radiotherapy: clinical relevance. Discov. Med. 9, 119, 2010.

119. CURTIN J. F., KING G. D., CANDOLFI M., GREENO R. B., KROEGER K. M., LOWENSTEIN P. R., CASTRO M. G. Combining cytotoxic and immune-mediated gene therapy to treat brain tumors. Current topics in medicinal chemistry, 5, 1151, 2005.

120. GRIDLEY D.S., RIZVI A., LUO-OWEN X., MAKINDE A.Y., PECUAT M.J. Low dose, low dose rate photon radiation modifies distribution and gene expression in CD4+ T cells. J. Radiat. Res. 50, 139, 2009.
121. MILACIC S., SIMIC J. Identification of health risks in workers staying and working on the terrains contaminated with depleted uranium. J. Radiat. Res., 50, 213, 2009.

122. MILACIC S. Health investigations of depleted uranium clean-up workers. Medicina del Lavoro, 99, 366, 2008.

123. DOWN J. D., BOUDEWIJN A., VAN OS R., THAMES H. D., PLOEMACHER R. E. Variations in radiation sensitivity and repair among different hematopoietic stem cell subsets following fractionated irradiation. Blood, 86, 122, 1995.

124. BOTNICK L. E., HANNON E. C., VIGNEULLE R., HELLMAN S. Differential effects of cytotoxic agents on hematopoietic progenitors. Cancer Res., 41, 2338, 1981.

125. MA S., LIU X., JIAO B., YANG Y., LIU X. Low-dose radiation induced responses: focusing on epigenetic regulation. Int J. Radiat. Biol. 86, 517, 2010. 